\title{
A SONG IN THE DARK. FRANCIS OF ASSISI'S CANTICLE OF BROTHER SUN
}

\author{
WILLEM MARIE SPEELMAN*
}

Tilburg University

\begin{abstract}
The Canticle of the Creatures or Canticle of Brother Sun is based on a particular way of perceiving reality. Francis, who had turned away from 'the world', discovered a different way of looking at it. This is a divine way of perceiving, in which the senses do not grasp reality, but accept it as it communicates itself. This way of perceiving is only possible if one does not attempt to master the environment, but allows one's senses to be weak. It is significant, therefore, that this song of praise was born at a moment of the utmost despair and weakness. The song's content is in line with this weak perception: it is not about Francis who praises God and (or for) His creatures, but rather it is a testimony that the creatures-the elements-are already praising God, and a prayer that He should let Himself be praised by the creatures. Also in line with this weak perception is the fact that the creatures are praised just as they communicate themselves to Francis: as bodies. The theology of this song is that the creatures through their bodies resonate (strengthen, and colour) the blessings that come from God, thereby making His blessing present here on earth. Francis' role is to give a voice and a language to the heavenly praises as they resound in his environment. The transformative power of this song is that we, whether consciously or not, do the same thing when we participate in this song.
\end{abstract}

KEY-WORDS: St. Francis, Canticle of the Sun, hymn, nature, creation

${ }^{1}$ Altissimu onnipotente bon signore, tue so le laude, la gloria e l'onore et onne benedictione.

2 Ad te solo, altissimo, se konfano, et nullu homo ene dignu te mentovare.

${ }^{3}$ Laudato sie, mi signore, cun tucte le tue creature, spetialmente messor lo frate sole, lo qual'è iorno, et allumini noi per loi.
${ }^{1}$ Most High, all-powerful, good Lord, Yours are the praises, the glory, and the honor, and all blessing.

${ }^{2}$ To You alone, Most High, do they belong, and no human is worthy to mention Your name.

${ }^{3}$ Praised be You, my Lord, with all Your creatures, especially Sir Brother Sun, Who is the day and through whom You give us light. 
${ }^{4}$ Et ellu è bellu e radiante cun grande splendore, de te, altissimo, porta significatione.

${ }^{5}$ Laudato si, mi signore, per sora luna e le stelle, in celu l'ài formate clarite et pretiose et belle.

${ }^{6}$ Laudato si, mi signore, per frate vento, et per aere et nubilo et sereno et onne tempo, per lo quale a le tue creature dai sustentamento.

${ }^{7}$ Laudato si, mi signore, per sor aqua, la quale è multo utile et humile et pretiosa et casta.

${ }^{8}$ Laudato si, mi signore, per frate focu, per lo quale enn' allumini la nocte, ed ello è bello et iocundo et robustoso et forte.

${ }^{9}$ Laudato si, mi signore, per sora nostra matre terra, la quale ne sustenta et governa, et produce diversi fructi con coloriti flori et herba.

${ }^{10}$ Laudato si, mi signore, per quelli ke perdonano per lo tuo amore, et sostengo infirmitate et tribulatione.

${ }^{11}$ Beati quelli ke 'l sosterrano in pace, ka da te, altissimo, sirano incoronati.

${ }^{12}$ Laudato si, mi signore, per sora nostra morte corporale, da la quale nullu homo vivente pò skappare.

${ }^{13}$ Guai a cquelli, ke morrano ne le peccata mortali: beati quelli ke trovarà. ne le tue sanctissime voluntati, ka la morte secunda nol farrà male.
${ }^{4}$ And he is beautiful and radiant with great splendor; and bears a likeness of You, Most High One.

${ }^{5}$ Praised be You, my Lord, through Sister Moon and the stars, in heaven You formed them clear and precious and beautiful.

${ }^{6}$ Praised be You, my Lord, through Brother Wind, and through the air, cloudy and serene, and every kind of weather, through whom You give sustenance to Your creatures.

${ }^{7}$ Praised be You, my Lord, through Sister Water, who is very useful and humble and precious and chaste.

${ }^{8}$ Praised be You, my Lord, through Brother Fire, through whom You light the night, and he is beautiful and playful and robust and strong.

${ }^{9}$ Praised be You, my Lord, through our Sister Mother Earth, who sustains and governs us, and who produces various fruit with colored flowers and herbs.

${ }^{10}$ Praised be You, my Lord, through those who give pardon for Your love, and bear infirmity and tribulation.

11 Blessed are those who endure in peace for by You, Most High, shall they be crowned.

12 Praised be You, my Lord, through our Sister Bodily Death, from whom no one living can escape.

${ }^{13}$ Woe to those who die in mortal sin. Blessed are those whom death will find in Your most holy will, for the second death shall do them no harm. 
${ }^{14}$ Laudate et benedicete mi signore, et rengratiate et serviateli cun grande humilitate.
14 Praise and bless my Lord and give Him thanks and serve Him with great humility. (Armstrong, Hellmann, Short 2000: 113-114)

The Canticle of Brother Sun, or Canticle of the Creatures, is generally considered to be the first laude in the Umbrian language, and is Francis of Assisi's most famous text. In the song, a critically ill Francis clothed himself with the joy of the Lord, whom he recognised in the cosmic brotherhood of creation. With extraordinary skill, he wove his mission to spread penance and praise, his sense of immediate involvement with God, his mission of peace, and his bodily experience of God's coming kingdom into a single hymn of praise. He charged his friar brothers to sing this song of praise everywhere, to share in a poetic way what every human being even today needs so badly: joy, as the fulfilment of every shortcoming.

\section{Seeing Nature as Creation}

The Dutch Franciscan friar Jan van den Eijnden is wont to say that Francis of Assisi really did not care very much about nature. What we call nature, he regarded as creation. Creation is nature seen in the light of the Creator. And in the light of the Creator, all creatures are good the way they were created. Creation is not a nihilist void but fullness, not a cruel struggle but community, not an inanimate process but life. This perspective seems too good to be true, but Francis clearly managed to see creation in this way. He was only able to do this because he chose a difficult way of life: he chose the path that leads to the Most High by way of the most vulnerable. It is therefore important to know that Francis wrote the Canticle of Brother Sun when he was ill and miserable. When Eloï Leclerc wrote beautifully about the Canticle of Brother Sun, he concluded his book by remarking that the hymn only really came to life for him when it was sung in a train heading for Dachau while one of his fellow friars was dying of hunger and exhaustion (Leclerc 1982: 184-191). It is evidently only given to humans to see creation when they are at their most vulnerable, and when they are able, for a brief moment, to see as God sees.

\section{Seeing as Humans Do, and Seeing as God Does}

Creation is a perspective, a way of seeing. In the poetic story of the creation in seven days, God looks at creation every day and says: 'Yes, it is good!' God blesses his creation by 'speaking well of it' (bene dicere). Seen in this way, the creation narrative is perhaps not so much an explanation for the origin of the world as a poetic text that sings about God who blesses his creation every day by looking at it. The seeing that God does in the creation narrative is a form of recognition: God, who alone is good (Matthew 19:17), sees the good 
in his creature. The creature's face reflects the face of God. In this way, God is present to all of his creatures. This very ancient way of seeing nature is a truly authentic one, no less so in our time than in the days of Francis of Assisi. But in order to be able to see in this way, humans must themselves become creatures, rediscover their God-like face, and see with eyes that say: 'yes, it is good!'

Humans normally do not look with their eyes, but with their interpreting and concealing brain. This is a bold statement, perhaps, but the theory that underpins it is nothing new. The Swiss linguist Ferdinand de Saussure taught his students that when we hear someone speak, we do not listen to sounds, but to acoustic images (images acoustiques) in our head (De Saussure 1972). He calls these acoustic images 'phonemes'. Phonemes are 'overlaid' over the sounds, as it were, so that we are able, for instance, to understand various pronunciations of the letter $[\mathrm{r}]$ as one and the same latter ' $\mathrm{r}$ '. The result, however, is that we are not listening to the sound, but to the phoneme (which is an image). De Saussure goes even further by saying that words, which are composed of acoustic images, do not refer to things in the world, but to conceptual images in our brain: the Englishman says [ka'], we hear 'car' and see the image of a car. Seen in this light, the entire process of language takes place within our brain, and has no immediate reference to the world outside language. This theory in fact indicates that we do not see reality-nature around us for instance-as it is, but that we always see it in the light of the narrative we tell about it. The philosopher Martin Heidegger has pointed out that a hydraulic engineer will look differently at the Rhine than a poet does (Heidegger 2004). The hydraulic engineer has a technical eye and sees water as a possible source of energy, while the poet sees it as a possible source of beauty. It could be objected that we can also see water the way water is itself. But this is almost impossible. We cannot simply 'step out' of our narratives to see nature as it really is. We would somehow have to succeed in silencing our language and all our narratives. This can only be done if we stop appropriating the world, and if we silence all our human faculties for understanding the world. Even then we can only hope that God may afford us a view of his creation. Shutting down human faculties to understand the world is something a mystic may do when he closes his eyes and ears. But that is not what Francis did; he was just too weak to gain any kind of control over his surroundings. His success in transforming his weakness into strength by turning it toward God (cf. 2 Corinthians 12:9) is what made Francis great.

\section{A Hymn of Praise from the Depths of Despair}

In The Assisi Compilation, friars who lived with Francis gave an account of how the Canticle of Brother Sun was written (Armstrong, Hellmann, Short 2000: 184-187; Sier, Loeffen, Jansen 1985). At the end of his life-long quest for life 
as God intended it to be lived, Francis was worn out. His body was stigmatised, he suffered from photophobia and exhaustion, was depressed, and the tensions that existed within the fraternity preyed on his mind. As he lay in a cabin near San Damiano, Francis felt the strong temptation to give everything up (Merlo 2001: 12-14). The story goes as follows:

... Blessed Francis lay there for more than fifty days, and was unable to bear the light of the sun during the day or the light of a fire at night. He stayed in the dark in the house, inside that little cell. In addition, day and night he had great pains in his eyes so that at night he could scarcely rest or sleep. This was very harmful and was a serious aggravation for his eye disease and his other illnesses.

Sometimes he did want to rest and sleep, but there were many mice in the house and in the little cell made of mats where he was lying, in one part of the house. They were running around him, and even over him, and would not let him sleep. They even disturbed him greatly at the time of prayer. They bothered him not only at night, but also during the day, even climbing up on his table when he was eating, so much so that his companions, and he himself, considered it a temptation of the devil, which it was.

One night as blessed Francis was reflecting on all the troubles he was enduring, he was moved by pity for himself. 'Lord', he said to himself, 'make haste to help me in my illnesses, so that I may be able to bear them patiently'. And suddenly he was told in spirit: 'Tell me, brother, what if, in exchange for your illnesses and troubles, someone were to give you a treasure? And it would be so great and precious that, even if the whole earth were changed to pure gold, all stones to precious stones, and all water to balsam, you would still judge and hold all these things as nothing, as if they were earth, stones and water, in comparison to the great and precious treasure which was given you. Wouldn't you greatly rejoice?'

'Lord', blessed Francis answered, 'this treasure would indeed be great, worth seeking, very precious, greatly lovable, and desirable'. 'Then, brother', he was told, 'be glad and rejoice in your illnesses and troubles, because as of now, you are as secure as if you were already in my kingdom'.

(Assisi Compilation, no. 83)

The decisive aspect is that Francis saw the temptation as a test, and that he did not stop turning to God (Fumagalli 2005: 33). Francis' prayers were answered by a divine inspiration, an inspiration which is reminiscent of the words Jesus spoke to the good thief on the cross: 'today you will be with me in paradise' (Luke 23:43). The next day he told his companions of his consolation, and then sat up, withdrew in contemplation, and began: 'Most High, all-powerful, good Lord...' He composed a melody for the song and taught it to his brother friars: whenever they have preached a sermon anywhere, they were to sing this canticle of praise as minstrels of the Lord. He later added the verses 10 and 11, following a furious quarrel between the bishop and the mayor of Assisi (Assisi Compilation, no. 84; see Nolthenius 1988: 271 and 183, 
note 2). And the verses 12 and 13 were added when Francis felt death approaching (Assisi Compilation, no. 7). ${ }^{1}$ All this is according to the witness of the brother friars who were with him.

There is admittedly some debate as to the veracity of this romantic story. Fumagalli, for instance, has contended that the song is too much of a unity to accept that there were later additions to a text that had been finished previously (Fumagalli 2005: 20 and 46). Moreover, there are some traces, or rather 'prefigurements' of the Canticle of Brother Sun in earlier texts: according to the accounts, Francis had already addressed creatures as brothers and sisters, called God the Most High (RnB [= The Earlier Rule] 17:17, in Armstrong, Hellmann, Short 1999: 63-86), and said that no human was worthy of mentioning His name before ( $\mathrm{RnB}$ 23:5). But one thing does not exclude the other. In a poetic process in what was still mostly oral tradition, it is quite common that texts are composed through a longer process of development. Nor is it unusual that events and previous discoveries would reappear in such a text. It might be said that the song was not fully finished until divine confirmation occurred in the way that has just been described.

\section{A Sermon Hymn}

The song's purpose was identical to that of the friars' mission to preach penance and praise. Francis wanted his friars to use this hymn in their preaching. He wanted them to use it at the conclusion of their sermons for the people, adding the following words: 'We are minstrels of the Lord, and this is what we want as payment; that you live in true penance' (Assisi Compilation, no. 83). Seen against this background, it does not surprise that Francis composed the Canticle of Brother Sun in the vernacular. Because although the Canticle itself is considered to be the first song composed in Umbrian, minstrels were already singing songs in the vernacular in villages and towns (Lug 1997: 300). It is quite possible that the Friars Minor presented themselves as a kind of minstrels and that they used the style of the minstrels to attract the attention of the crowds (Mantz-Van der Meer 1989: 269-272).

The Canticle of Brother Sun has been called a sung sermon (Rotzetter 1982: 50-53). The Friars Minor preached by giving admonitory lay sermons for the ordinary people outside the church, without touching on any theological issues: their preaching was an enthusiastic call to praise and penance. Anton Rotzetter has demonstrated structural similarities between the sermon schedule from the preliminary edition of the Rule (RnB 21:1-9) and the Canticle of Brother Sun. According to the sermon schedule, the sermon should begin with a call to praise ( $\mathrm{RnB}$ 21:2), before admonishing the audience to do penance

1 The crux of this story is that the friars will always be able to find Francis in the joy of the Lord. In the eyes of the Lord-or in other words: from a heavenly perspective-death is good too.

PERICHORESIS 14.2 (2016) 
(RnB 21:3-9). These similarities are unmistakeable. But because the hymn itself is addressed primarily to God, the Canticle of Brother Sun is a sermon that draws the audience into Francis' own involvement with God and the world.

\section{According to a Biblical Model}

If Francis did spend a longer period of time writing the Canticle of Brother Sun, it is not unlikely that he worked on the basis of biblical models that he knew from the divine office. In the oral tradition that was proper to him, these models are not developed and imitated, but appropriated as if they were a language. Giovanni Pozzi has contended on the basis of a careful comparison of the two texts that the Canticle of Brother Sun is modelled on the Benedicite or the Canticle of the Three Youths, a hymn of praise that Francis sang every Sunday morning at Lauds (Pozzi 1990). He has even called it an adaptation of the song of Daniel. There are in fact many differences, and it is precisely in this comparison that the Canticle of Brother Sun appears as an original composition.

\section{The Text of the Canticle}

An analysis of the text reveals many original elements in the Canticle of Brother Sun. First, it is like a ladder, consisting not of various creatures as in the canticle of Daniel, but of the elements. Its best known original feature is, of course, that Francis calls created elements brothers and sisters. Francis then sings of the celestial bodies, the elements, and humans in their responsibility to create living space for the creatures. Fourthly, he calls on all creation to do what it is called to do: to share in the heavenly hymn of praise. Analysis has also shown that Christ himself is present in a hidden manner in the Canticle of Brother Sun, as he is in Francis himself. But let us begin by establishing that it is indeed a hymn of praise.

A Hymn of Praise. The exhortation Laudato si' is a special variant of 'hallelujah, praise the Lord' as it occurs for instance in Psalm 148, and of benedicite, 'bless', from the Canticle of the Three Youths in Daniel. In these examples, creation is called upon to praise the Lord. Augustine commented on this as follows: 'Halleluia. Praise the Lord, you say to your neighbour, he to you: when all are exhorting each other, all are doing what they exhort others to do' (en. Ps. $148,2)$.

But Francis addresses the Lord himself to be praised. It is as if the Lord is the momentum of the pendulum swing that is the hymn of praise: He is the source and destination - tue so le laude and at te solo se konfano — of a movement of praise that goes out from God to his creatures ('yes, you are good!'), and from the creatures to God (Speelman 2016a: 147; 2016b). In his Canticle of 
Brother Sun, Francis addresses the source and destination of all praise, the silence between two alternating sung Psalm verses. In verse 3, the addressee is extended to include all his creatures-Laudato sie, mi signore, cun tucte le tue creature - as if in the swing of the pendulum Francis has recognised a single choir. In his commentary on the Psalms, Nico Tromp has said that all of creation is present in the temple on account of God's presence there. This is interpreted further here: the hymn of praise itself is an expression of the enduring presence of God to all his creatures (Tromp 2002: 289). Francis then praises the creatures themselves, by recognising and naming their good qualities: 'he is beautiful and radiant with great splendour!' Is this not the meaning of every blessing, to bring to light the other's good aspects? Humans do this by recognising and naming the good, just as God did at the close of each day of creation. And a human being can only recognise the good if this good is also present within himself or herself. In this way, the hymn of praise is a way of assenting to the hymn of praise that is already ongoing. Francis does this through his poetic expression, his brother friars do this by using their voices and their feet to make it resound everywhere. This is how theyas well as we, if we apply the last verse to ourselves-bring to light the good of creation, and therefore of God.

Descending from Above, and then Ascending again. When we take a closer look at the text, it becomes clear that the Canticle of Brother Sun contains a descending movement, beginning with the Altissimo (verses 1, 2, 4, 11) who is mentioned four times. If you run past the verses one by one, you get the impression you are coming down a ladder: from the Most High in verse 1 to the great humility in the final verse. The rungs of the ladder are formed by the celestial bodies, beginning with Sir Brother Sun, then the elements wind, water, and fire, finishing with Sister Mother Earth. It is important to note that the Messor (Lord) and the matre (mother) have been woven into the text.

$$
\begin{array}{ll}
\text { MESSOR } & \text { frate sole — sora luna } \\
& \text { frate vento-sor aqua } \\
& \text { frate focu—sora MATRE terra }
\end{array}
$$

Only then is there mention of humans, in their most humble state, i.e. as bearers of infirmity and tribulation, and as mortal beings. This might be called the counterpoint, where the descent turns into a hymn of praise that arises from the depths and returns to the Most High (Goorbergh, Zweerman 2003: 70). This way, the song sings of the total space of creation in an alternating movement.

Brothers and Sisters in the Flesh. The scheme presented above immediately highlights the other original element of the Canticle of Brother Sun: creature

PERICHORESIS 14.2 (2016) 
bodies are addressed as brothers and sisters. Francis had called creatures brothers and sisters long before, but then he had been addressing a lark, for instance, or a fish. In the Canticle it is not primarily flowers and plants, birds and animals, human beings and angels, who are addressed as brothers and sisters, but bodies: the celestial bodies, the elements of which the bodies of this world are composed, physical suffering and bodily death. It seems as if Francis wanted to descend to the depth, to the very weakness that unites creation and gives it its own position vis-à-vis God. It must be noted that in this respect Francis goes further than Augustine, who mistrusts the body as the singer of a hymn of praise. For Augustine it is the soul that sings the Lord's praise: $Q u i$ dicit: 'Lauda, anima mea, Dominum?' Caro non dicit (en. Ps. 145, 3). This, however, does not contradict Francis, whose soul brings bodies to life, as it were: the soul 'says' (dicit) the hymn of praise, but the bodies make it resound.

The physicality of creation is not celebrated as dead matter, but Francis' imagination connects it with his soul, thus bringing it to life (Leclerc 1982: 24-30). Even this imagination is a physical process. Francis feels the qualities of the creatures resonate in his own body, qualities that are good and therefore come from God. It is as if Francis and the creatures form a pure physical sound box that is made to resonate by the heavenly harmony, which is such that it has no choice but to resound. Francis' soul recognises the beauty of the sun, the preciousness of the stars, the humility of the water. He can see, and is obliged to acknowledge, that creation consists of animated and living bodies. These animated bodies are what they always were: brothers and sisters. The 'animation' comes from God, just as all good things come from God. Viewed in this perspective it is no surprise that the Canticle of Brother Sun only mentions the good aspects of the elements; they are from God, and what comes from God, sings his praises. Ultimately, God himself is the One Who Praises, the soul who brings creation to life.

With Their Good Qualities. The qualities that Francis recognises in creation, are expressed in adjectives in this poem. Where the Benedicite mentioned before merely sums up different creatures, Francis in the Canticle of Brother Sun adds qualities to these creatures, qualities that moved him.

To provide insight into the poem's pattern of the composition, I will refer here to Giovanni Pozzi's analysis (quoted in Fumagalli 2005: 45-46). The number three is the organising principle in the section on the celestial bodies: sun, moon, and stars: clear, precious, and chaste. Three of the four elements are each given four adjectives: the wind is aere et nubilo et sereno et onne tempo ('cloudy and serene, and every kind of weather'), the water is utile et humile et pretiosa et casta ('useful and humble and precious and chaste'), the fire is bello et iocundo et robustoso et forte ('beautiful and playful and robust and strong'). The earth, sustenta et governa et produce diversi fructi con coloriti flori et herba 
('sustaining and governing and producing various fruit with coloured flowers and herbs'), forms an exception to this rule. The part about humans (verses 10-13) is dominated by the number two: love and forgiveness, infirmity and tribulation, woe to them and blessed those. As a whole, the Canticle of Brother Sun is therefore held together by three (celestial bodies) + four (elements) + two (human categories) $=$ nine creatures who praise. And the number nine returns in the number of exhortations to praise, eight times 'praised be' (verses 3, 5, 6, 7, 8, 9, 10, and 12) and once 'praise' (verse 14). Fumagalli sees this complex unity not only as proof that the Canticle of Brother Sun was written as a whole, but also that it is unthinkable that it would have been handed down only in oral form (Fumagalli 2005: 46). And reconstructions benefit from a clear structure. It is a mistake, however, to think that oral traditions are any less sophisticated than written ones. The act of remembering is not so much simply a matter of reproducing something, but an act of reconstruction, in which striking characteristics play an essential role (Damasio 2004: 109-134). The cursus and rhyme, as well as numerical features make remembering easier rather than more difficult. This is why it is quite possible not only that Francis composed or recomposed the Canticle of Brother Sun in his mind before transmitting it orally, but also that he adapted the song on occasion without detracting from its strong unity.

In addition to their number, the content of the adjectives is also important. They can tell what precisely it is in creation that caused Francis' soul to recognise and his body to resonate. This issue involves briefly revisiting the previous section, where we wrote that Francis recognises animated and living bodies that are part of the cosmic brotherhood. We can now interpret this more precisely because the adjectives all point to the creating of living space. The celestial bodies, weather, water, fire, and earth, human beings who share life together in peace, and finally a good death, all create space for life as God gave it.

\section{The Word per}

The repeated call to praise the Lord contains an ambiguity that is caused by the word per. Some translations have Francis sing out his gratitude to God for the creatures (cf. the French pour), others translate per by 'through' (cf. the French par). Just as in Psalm 148, the creatures in the Canticle of Brother Sun are presented as the ones who bless God. Church fathers such as Augustine wrote that creatures in their beauty are themselves a hymn of praise to the Creator (en. Ps. 144, 13). In this way, even the dumb earth has a voice, that is if we lend it our voice (Francis' soul which brings dead matter to life). If we see these creatures and say that they are good or beautiful, then we are praising the goodness and beauty of the Creator. 
Nevertheless, if we do this, then we are saying what God said when $\mathrm{He}$ saw his creatures. We are actually speaking his very words, and in doing so we imitate him. As Francis indicates in verses 1-2: God is the One Who Praises as well as the Praised One. This interpretation of the Canticle of Brother Sun is confirmed by the Liturgy of the Hours, which states that Christ Himself sings the canticle of praise, together with the angels and saints. God's Son is Himself the One Who Praises, while inviting us to take part in his song of praise (Institutio Generalis de Liturgiam Horarum, nos. 3-9). When Francis says that 'no human is worthy to mention God's name' (verse 2), then we could add, in reference to the first lines, 'except You Yourself, because Yours are the praises and to You alone do the praises belong' (verses 1-2). We may conclude that the canticle of the creatures is aimed at a participation of the creatures in the heavenly hymn of praise, which has its origin and its object in God ( $D e$ Benedictionibus, praenotanda generalia, no. 1).

Serve Him with Great Humility. At the end of the descending movement stands the call to praise Him, to bless Him, as well as to thank and serve Him with great humility. Some questions, however, need to be asked in connection to this particular call. For instance, to whom is this call addressed? To the creatures? The audience? Francis himself? To all of these, of course, but it is essential that they are all invited to closely imitate Christ in this respect, because $\mathrm{He}$ is the One who made this descending movement. It is crucial at this point to ascertain this essential aspect; to give just one example, Romano Guardini has pointed out that meekness, the descending movement from up above to down below, is a divine virtue (Guardini 2002: 379). One learns from Francis' poem that God Himself is meek, because He has emptied Himself in Christ and became man. Man even owes his humility to God. Viewed in this light, the humility that concludes the song is nothing less than a call to be pure reflections of God, that is, to be truly human. Leclerc has spoken in this context of the 'poetry of reconciliation', because Francis reconciles himself to himself as being no more than a human being: he connects his most exalted aspirations with his lower and darker belonging to the earth (Leclerc 1982: 42). The reality of reconciliation flows from his encounter with God, presented here as the Most High, precisely in the place and at the time that he himself had sunk to his lowest point. It is precisely here that he finds God. As one reads through the poem, one cannot avoid the issue that it is perhaps the task of humans to connect these things to each other in language, and to name them. The world of creation needs a human like Francis to give poetic expression to the creatures' hymn of praise, and to make this hymn audible in song. Thanks to Francis, all the elements of creation, such as the sun, the moon, and the stars have received a voice. 


\section{The Transformative Power of the Canticle of Brother Sun}

Now we have completed our analysis of the Canticle of Brother Sun, the transformative aspects have come to light. The Canticle of Brother Sun allows the reader to see with new eyes, and brings him or her from darkness to light.

Naming without Appropriating: Giving Back. We have interpreted the Canticle of Brother Sun in the light of the human task to give the creatures a voice. God gave Adam this task, when God made him share in his faculty of speech. The philosopher Walter Benjamin has emphasised that speaking is originally naming (Benjamin 1992: 30-49). To name is to answer to the spirit that speaks from a creature. Man names the creature in accordance with the way it appears to him. This also means that speaking, naming, first and foremost is looking and listening to the creature as God created it. And because all creatures were created from God's word-'and God said' - the task of giving voice to the creatures ultimately amounts to responding to God's voice which resonates in his creatures. As Benjamin puts it: 'the residue of the creative word of God'.

This also means that creatures belong to God, and not to humankind. Belief in creation has as its moral consequence that humans should not appropriate anything. We may not take possession of anything, but we may make them ours: by attaching ourselves to the creatures and by recognising that everything belongs to God. Francis always meticulously guarded against taking pride in the good deeds he did: all good things come from God and no one should take pride in them or treat them as if they belonged to him or her (RnB 17:17). By viewing the world as creation, he relinquished control of it, and let it be the way God wanted it to be. In this way, humans give to God what belongs to Him, including themselves. By giving themselves back to God, humans show that they are a reflection of God. And giving yourself back, which is something that follows surrender, takes the form of a hymn of praise.

However paradoxical it may seem, the result of this fundamental attitude of humility and gratitude is that humans are exalted to a nearly divine state (cf. Admonitions 5:1 in Armstrong, Hellmann, Short 1999: 128-137; Psalm 8:6). Obviously Francis is able to recognise the good, and he is compelled to acknowledge that God sees the world through his eyes. This result points to the spirituality, that is the transformative power, of the Canticle of Brother Sun.

A Song in the Dark. It is quite possible that Francis wrote the Canticle of Brother Sun during a process that lasted longer than the account quoted above suggests. However, it remains significant that it was sung at precisely the moment that Francis' eyes could not bear the sunlight anymore and that he was inclined to give everything up. This shows that the Redeemer is at hand when 
humans are at their most vulnerable-and this is something that is at the very heart of Franciscan spirituality. Our fragility as humans is not a problem that we should try to avoid, or take care of, or protect; on the contrary, it is the gateway to God, who came to meet us in the hour of our deepest misery. This does not mean, as the pious slogan would have, that God is with the weak, or that He takes the side of the oppressed. No, God is with all human beings, but He is precisely there where they dare not be themselves, where they cannot bear themselves or their surroundings, where they are at their weakest (cf. 2 Corinthians 12:9).

Seeing with New Eyes. When Eve and Adam placed the tree of the knowledge of good and evil at the centre of their lives, everything became a problem in their eyes, their own vulnerability in particular. Humankind learned to deal with that problem: by protecting its weakness with knowledge, culture, cities, and weapons. Francis tried this too, when he was still a young merchant who wanted to be a knight (Vauchez 2012: 7-19). But by imitating Christ, Francis placed the other tree, the tree of life, at the centre of his life. What had previously been a problem, became a mystery for Francis (cf. Encyclical Laudato si', no. 12). And his vulnerability became a special sensibility that allowed him to perceive things in a different way: what had been bitter, became sweet, and what had been sweet became bitter (Testament 1-3, in Armstrong, Hellmann, Short 1999: 124-127). As has been seen, creation is a question of taste. Francis acquired the taste of creation by 'following in the footsteps of Jesus' (RnB 1:1 sequi vestigia eius), which points to a very physical form of imitation. In this way he tasted a form of life that was unambiguously subject to God's lordship: the Kingdom of God. But they who follow Jesus' life, must also accept his suffering, his 'tribulations', and must become vulnerable. Francis accepted life precisely as it was given to him. This meant that his weak points were laid bare. As soon as he abandoned his resistance, his weak points turned out to be extremely sensitive antennae for a world that almost no one can see. He saw God's Kingdom, Creation, with new eyes, and he saw that it was very good.

\section{Bibliography}

Armstrong RJ, Hellmann JAW, Short WJ, eds (1999) Francis of Assisi: Early Documents, volume 1: The Saint. New York, NY: New City Press).

Armstrong RJ, Hellmann JAW, Short WJ, eds (2000) Francis of Assisi: Early Documents, volume 2: The Founder. New York, NY: New City Press.

Augustine Enarrationes in psalmos (en. Ps.).

Benjamin W (1992) Sprache und Geschichte: Philosophische Essays. Stuttgart: Reclam. 
Damasio AR (2004) De vergissing van Descartes: Gevoel, verstand en het menselijk brein. Amsterdam: Wereldbibliotheek.

De Saussure F (1972) Cours de linguistique générale. Paris: Payot.

Fumagalli E (2005) Saint Francis, the Canticle, the Our Father (Greyfriars Review Supplement 19). St Bonaventure: Franciscan Institute.

Guardini R (2002) The Lord, with a New Introduction by Joseph Cardinal Ratzinger. Washington, DC: Regnery.

Heidegger M (2004) Die Frage nach der Technik (1953, Vortrag). In Heidegger M, Vorträge und Aufsätze. Stuttgart: Klett-Cotta.

Leclerc E (1982) Symbolen van de Godservaring: Een analyse van het 'Zonnelied' van Franciscus. Haarlem: Gottmer.

Lug R (1997) Minnesang und Spielmannskunst. In Möller H and Stephan R (eds) Neues Handbuch der Musikwissenschaft, Band 2: Die Musik des Mittelalters. Darmstadt: WBG, pp. 294-324.

Mantz-van der Meer AEG (1989) Op zoek naar loutering: Oorsprong en ontwikkeling van de enkratitische ascese tot in het begin van de dertiende eeuw n. Chr. Hilversum: Verloren.

Merlo GG (2001) The story of Brother Francis and the Order of Friars Minor. Greyfriars Review 15(1): 1-33.

Nolthenius H (1988) Een man uit het dal van Spoleto: Franciscus tussen zijn tijdgenoten. Amsterdam: Querido.

Pozzi G (1990) Canticle of Brother Sun: From Grammar to Prayer. Greyfriars Review 4(1): 1-21.

Rotzetter A (1982) Gott in der Verkündigung des Franz von Assisi. Lau-rentianum 23: 40-76.

Sier M, Loeffen A, Jansen A, eds (1985) Herinneringen aan broeder Franciscus. Haarlem: Gottmer.

Speelman WM (2016a) Zie dat ik ben: Christelijke spiritualiteit als weg tot menswording. Heeswijk: Berne Media.

Speelman WM (2016b) How low can you go. In Sarot M, van Wieringen A (eds) Christ's Descent into Hell. Leiden: Brill. (pro manuscripto)

Tromp N (2002) Psalmen 101-150. 's-Hertogenbosch: KBS.

van den Goorbergh E, Zweerman Th (2003) Franciscus van Assisi: Over zijn evangelische bezieling en de betekenis ervan voor onze tijd. Nijmegen: Valkhof.

Vauchez A (2012) Francis of Assisi: The life and afterlife of a medieval saint. New Haven, CT: Yale University Press. 